5. Коваленко А.Г. Антиномизм и бинарный архетип в структуре художественного конфликта / А.Г. Коваленко // Вестник РУДН, Литературоведение. Журналистика. 2003-2004. - № 7-8 - C.5-14.

\title{
Элементы волшебной сказки в рассказе А.П. Чехова «Белолобый»
}

\author{
Горохова Н.Д., студентка, \\ Северо-Восточный федеральный университет, \\ 2. Якутск \\ E-mail: nyurquyana.gorokhova@yandex.ru
}

\section{Научный руководитель: к.филол.н., доцент Ощепкова А.И.}

Антон Павлович Чехов вошел в историю детской русской литературы благодаря своим двум произведениям: «Каштанка» и «Белолобый». Из письма к издателю Г.И. Россолимо он писал: «То, что у меня, по-видимому, подходит для детей, — две сказки из собачьей жизни...» [4, стр. 19]. Такое определение многозначительно: тут и признание сказки как жанра, специально приспособленного детям, тут и ключ к разгадке авторского замысла. Ведь действительно, эти произведения напоминают сказки, у которых всегда счастливый конец. Рассказ «Белолобый» представляет собой образец сказочного жанра о животных, воспитывающие интерес и любовь к ним, демонстрирующие ценность таких чувств, как преданность и привязанность. В этой связи представляется интересным рассмотреть, каким образом сюжетная структура рассказа соответствует типологии сказочного повествования. Важно рассмотреть насколько четко прослеживаются элементы волшебной сказки, выявленных и описанных В.Я. Проппом, в рассказе А.П. Чехова.

Волшебную сказку Пропп трактует следующим образом: «рассказ, построенный на правильном чередовании приведенных функций в различных видах...» [2, стр. 91].

На основе обобщения различных фольклорных источников В.Я. Пропп сформулировал следующие четыре центральных положения, которые развиваются в «Морфологии...»: 1) «Постоянными, устойчивыми элементами сказки служат функции действующих лиц, независимо от того, кем и как они выполняются. Они образуют основные составные части сказки», 2) «Число функций, известных волшебной сказке, ограничено», 3) «Последовательность функций всегда одинакова...», 4) «Все волшебные сказки однотипны по своему строению, т.е. дают одинаковые функции» [2, стр. 22].

В.Я. Пропп к постоянным величинам относит тридцать одну функцию действующих лиц. Однако следует сказать, что не все функции присутствуют в сказках. Но последовательность остается всегда. Также устойчивы и семь действующих лиц: герой, антагонист (вредитель), даритель волшебных средств герою сказки, волшебный помощник, царевна или ее отец, отправитель, ложный герой, каждый из них имеет свой круг действий, выполняет одну или несколько функций.

В основу сюжета «Белолобый» положен рассказ о щенке, случайно оказавшегося в логове у волчихи. События развиваются очень увлекательно и динамично. Учитывая особенности детского восприятия, А.П. Чехов начинает повествование сразу, без 
вводных описаний и лирических отступлений По Проппу рассказ традиционно начинается как сказка, которая обычно завязывается с важного морфологического элемента, с исходной ситуации (i) - перечисления членов семьи: «ее волчата, все трое, крепко спали, сбившись в кучу, и грели друг друга». Вслед за ней перед нами та самая отлучка (e1) матери троих детенышей - волчихи на охоту. Она начинает выведывать (в), где находятся ее будущие жертвы. Итак, в ход действия вступает вредитель. Здесь важно отметить специфическую парную связь запрета (табу) и его нарушения. Пропп пишет: «Запрет в фольклоре всегда нарушается. Иначе не было бы сюжета. Запрет и нарушение - парная функция. Таких парных функций в сказке много» [2, стр.201]. Волчиха, несмотря на запрет (б1), измученная голодом, забралась к сторожу Игнату в хлев, где были ягнята. Запрет, естественно, нарушается (b1). Далее, вредителю выдаются (w3) нужные ему сведения: «И теперь, подходя к зимовью, она соображала, что в хлеву должны быть ягнята». Затем, традиционная функция - форма вредительства - «похищения» (A5): «Волчиха, испугавшись, схватила, что первое попалось в зубы, и бросилась вон...». Развитие действий происходит, когда волчиха узнала, что утащила щенка, а не ягненка, то оставила его и побежала прочь. Герой нашего рассказа - щенок увязался за ней и бежал до самого дома, где были ее волчата. В этом и кроются функции посредничество (B2) и отправка героя ( $\uparrow$ ). Сначала он начал лаять на них, но потом подружился, и они начали играть. Кульминационный момент приходится тогда, когда волчиха все-таки решила съесть щенка - функция дарителя (Д8). Но когда она подошла к нему, Белолобый лизнул ее в морду - реакция героя (Г7), и тогда волчиха щадит и отпускает его. Далее, щенок возвращается домой $(\downarrow)$. В эпилоге волчиха опять отправилась на охоту и наведалась в тот же хлев; герой и вредитель вступают в непосредственную борьбу (Б2), когда щенок своим лаем поднял шум, тем самым помешал ей утащить ягнят (П6). Когда сторож Игнат вышел с ружьем на крыльцо, перепуганная волчиха изгоняется (Н). Так и заканчивается рассказ.

Также, мы находим и другие элементы сказки - вспомогательные элементы при различных утроениях. Пропп пишет о том, что: «...утраиваться могут как отдельные детали атрибутивного характера (три головы змея), так и отдельные функции, пары функций (преследование - спасение), группы функций и целые ходы». Ровным образом, он отмечает, что повторение имеет равномерную («Ее волчата, все трое...», «Года три назад во время...») и нарастающую («Он спустил курок — ружье дало осечку; он спустил еще раз - опять осечка; он спустил в третий раз - и громадный огненный сноп вылетел из ствола и раздалось оглушительное «бу! бу!») формы. Игнат дважды пытается спустить курок ружья, и только в третий раз ему удалось это сделать. Тем самым, функция изгнания (Н) не может считаться самостоятельной функцией, ею только мотивируется тройное получение его.

Итак, исходя из вышеперечисленных функций по классификации В.Я. Проппа можно составить следующую схему: i e1 в 61 b1 w3 A5 В2 $\uparrow$ Д8 Г7 $\downarrow$ Б2 П6 Н. В рассказе мы выявили 15 функций действующих лиц «Белолобый», таким образом, представляет собой текст, который выстроен по канонам волшебной сказки П.Я. Проппа.

Список литературы:

1. Ожегов С.И. Толковый словарь русского языка. - М., 2001. 
2. Пропп В.Я. Морфология волшебной сказки. - М.: Изд-во “Лабиринт”, 2001. $192 \mathrm{c}$.

3. Чехов А.П. Белолобый. - М.: Детиздат, 1936. - 16с.

4. Чехов А.П. Письмо Россолимо Г.И., 21 января 1900 г. Ялта // А.П. Чехов. Полное собрание сочинений и писем: В 30 т. Письма: В 12 т. / АН СССР. Ин-т мировой лит. им. А.М. Горького. — М.: Наука, 1980. — С. 19-20

\section{Образ «маленького человека» в контексте мирового кино (на примере американской и французской кинокомедий)}

Григорьева А.Е., магистрант, Северо-Восточный федеральный университет, 2. Якутск

E-mail: lovemysister93@mail.ru

\section{Научный руководитель: к.филол.н., доцент Сабурова Н.В.}

В данной статье выявляются особенности реализации образа «маленького человека» на примере анализа американского ремейка французской комедии.

На сегодняшний день исследованию темы «маленького человека» посвящено огромное количество научно-исследовательских работ. Можно предположить, что причина подобной заинтересованности исследователей заключается в том, что забытые, всеми униженные люди зачастую обделены вниманием, а их проблемы и маленькие радости кажутся всем ничтожными и недостойными внимания. Образ «маленького человека» представляет собой человека низкого социального положения, который в большинстве случаев выступает в оппозиции к высокопоставленным людям. [3] Этот образ зародился и прочно закрепился в русской литературе в первой половине 19 века, а ее традиции вскоре были продолжены в зарубежной культуре. Так, Хамзаева X.M. в своей статье «Гоголевские традиции в зарубежной литературе XX века» рассматривает традиционные черты «маленького человека» в творчестве зарубежных писателей и утверждает, что гоголевские сюжеты, построенные на контрасте между мечтой и действительностью, живут в произведениях XX века и остаются очень убедительными. [1, стр. 132]

Следует утверждать, что у каждого писателя, как представителя определенной культуры, образ «маленького человека» приобретает свои отличительные признаки. Неизменным остается лишь одно: в начале произведения он страдает от несправедливости вышестоящего общества и влечет свое жалкое существование. А вот его дальнейшая судьба - намерен ли он бороться с несправедливостью или остается лишь смириться с этим - зависит уже от задумки самого автора. Тему протеста в реализации образа «маленького человека» можно считать решающей в реализации конкретных персонажей, произведений, а также жанра.

Создателем образа «маленького человека» в контексте мирового кинематографа, безусловно, считается Чарли Чаплин, герои которого говорили с экрана от имени маленьких, обиженных жизнью людей. Сам легендарный актер называл своего персонажа Бродягой, который появился впервые в фильмах «Необыкновенно 